\title{
The natural course of low back pain: a systematic critical literature review
}

\author{
Nadège Lemeunier ${ }^{1,2^{*}}$, Charlotte Leboeuf-Yde ${ }^{1,3}$ and Olivier Gagey ${ }^{1}$
}

\begin{abstract}
Background: Most patients in the secondary care sector consulting for low back pain (LBP) seem to have a more or less constant course of pain during the ensuing year. Fewer patients with LBP in the primary care sector report continual pain over a one-year period. However, not much is known about the long-term course of LBP in the general population. A systematic critical literature review was undertaken in order to study the natural course of LBP over time in the general population.

Methods: A search of articles was performed in Pubmed, Cinahl and Psychinfo using the search terms 'epidemiology'; 'low back pain' or 'back pain'; 'prospective study' or 'longitudinal study'; 'follow-up', 'natural course', 'course' or 'natural history'; 'general population' or 'working population'. Inclusion criteria were that one of the objectives was to study the course of (L)BP in the adult population, that the period of follow-up was at least 3 months, and that there were three points of observation or more. The review was undertaken by two independent reviewers using three checklists relating to description of studies, quality and outcomes. The course of LBP was established in relation to those who, at baseline, were reported not to have LBP or to have LBP. Would this course be stable, fluctuating, worsening, or improving over time? A synthesis of results in relation to common patterns was presented in a table and interpreted in a narrative form.
\end{abstract}

Results: Eight articles were included. Articles were different on time span, the number of surveys, and the definition of LBP. In six of the seven relevant studies, for those with no LBP at baseline, relatively substantial stable subgroups of people who continued to be LBP free were identified. In six of the seven relevant studies, definite stable subgroups of continued LBP were noted and improvement (becoming pain free) was never reported to be a common finding.

Conclusion: The status of LBP in individuals of the general population appears to be relatively stable over time, perhaps particularly so for those without LBP at baseline.

Keywords: Low back pain, Course, General population, Prospective study, Review

\section{Introduction}

Low back pain (LBP), which is a common disorder in the general population, was previously considered a generally short lasting disease with spontaneous recovery the most likely outcome. Because it is difficult to provide specific diagnoses to this condition, it became common to classify it according to the duration of the pain (i.e. acute, subacute or chronic) [1] with chronicity being

\footnotetext{
* Correspondence: nlemeunier@ifec.net

${ }^{1}$ Complexité, Innovation et Activités Motrices et Sportives, Bâtiment 335, UFR

STAPS, Université Paris Sud-11, Orsay Cedex 91405, France

${ }^{2}$ Institut Franco-Européen de Chiropratique, 72 Chemin de la Flambère,

Toulouse 31300, France

Full list of author information is available at the end of the article
}

considered relatively uncommon [2]. Nowadays, LBP is considered, rather, to be a recurring or persistent condition with a fluctuating course over time $[3,4]$. Yet, patients in the secondary care sector consulting for LBP seem to have a more or less constant course of pain during the ensuing year [5]. In contrast, fewer patients with LBP in the primary care sector report continual pain over a one-year period [6]. However, not much is known about the long-term course and different course patterns of LBP in the general population.

Our objective was to conduct a systematic critical literature review to improve our understanding of the natural course of LBP in the general population.

\section{Biomed Central}


Specifically, we wanted to find out the proportions of people with LBP at baseline who, when studied over prolonged periods of time, got better, worse, remained unchanged or fluctuated between LBP and no LBP. Similarly, we wanted to identify the most common course patterns for people without LBP at baseline; would they remain LBP free, develop LBP over time, or fluctuate between LBP and no LBP?

\section{Method}

\section{Search strategy}

A search for articles was performed in Pubmed, Cinahl and Psychinfo (until May 2012) using the search terms: 'epidemiology'; 'low back pain' or 'back pain'; 'prospective study' or 'longitudinal study'; 'follow-up', 'natural course,' 'course' or 'natural history'; 'general population' or 'working population'. None of our two universities had access to Embase. An additional citation search was performed of reference lists of the retrieved articles. We used no restrictions for date of publication or language.

\section{Inclusion and exclusion criteria}

Selection of articles were made by NL and verified by CLY according to predetermined criteria for inclusion and exclusion that were defined by NL and CLY in relation to the objectives of the review.

Articles were included if (one of) their stated objective(s) was to study the course of (L)BP in the general population, i.e. no studies concerning clinical populations or pregnancy were included. Further inclusion criteria were that LBP should be measured at baseline and at a minimum of 2 subsequent follow-ups. Studies should report on the same individuals $(n>100)$ for a minimum of 3 months and participants should be $\geq 18$ years old.

Because we expected to find only few studies of the general population, we also included studies of specific working populations if they did not represent hard physical work (e.g. construction workers) or extreme postures (e.g. painters, vineyard workers). Studies from the army or on compensation cases were also not accepted.

\section{Checklists}

Three checklists were created especially for this subject. These checklists related to the description of studies (Additional file 1: Appendix 1), their methodological quality (Additional file 1: Appendix 2), and their results. The criteria for methodological quality have been listed under three main headings: 1 ) representativeness of the study sample, 2) quality of data and 3) clear definition of LBP (Additional file 1: Appendix 2). The quality grid consisted of a slightly modified list of items previously used for prevalence studies of LBP [7]. All check-lists were tested by the reviewers for relevance and user friendliness on two articles, modified as needed to fit the purpose of the review, and tested once more prior to use.

\section{Review process and interpretation of findings}

Each article that fitted the criteria was independently and blindly reviewed by NL and CLY. In case of disagreement, the third author would be consulted. For all studies, the presence or absence of criteria was noted and the response rates were sought out or, if necessary, calculated. Only information mentioned in the methods or results sections was taken into account. A quality score was then calculated for each article according to the total number of acceptable criteria divided by the total number of relevant criteria. Each article was scrutinized for methodological quality, using the previously described scoring system but without determining an à priori cut-point for a minimal score, using it as an informative rather than a prescriptive score.

Results were taken into account only in relation to the pain aspect such as presence of LBP, duration, severity, or pattern; i.e. disability and consequences of LBP were not considered. The result sections were scrutinized for description of the course over time in relation to those who, at baseline, were reported a) not to have LBP or b) to have LBP. Results in each study were sought out in relation to whether absence or presence of LBP was stable, fluctuating, worsening, or - in the case of those having LBP at baseline -improving over time. The findings were reported in a table and interpreted in a narrative fashion. In addition, results were analyzed in relation to type of population and the number and spacing of surveys.

\section{Results}

\section{Number of articles}

Initially in Pubmed, 18 articles were considered suitable based on their title and study objectives (Additional file 1: Appendix 3). Of these, only 8 were retained after scrutiny of their text for all inclusion and exclusion criteria [8-15]. The 9 articles found with the search in Cinahl database overlapped with those already found in Pubmed. No relevant articles were found in the Psychinfo database. The additional citation search did not result in any relevant publications. An additional article was found in one of the authors' archives.

Some discussion between the reviewers was necessary for most articles, not because of disagreement but in order to clarify points that were unclear in the text; particularly in relation to the definition of LBP and the various response rates. There was no need to call in the third author for arbitration.

\section{Description of the articles}

The eight accepted articles had all been published since 1997, reporting on studies having been conducted 
between 1991 and 2005. Three had been carried out in the Nordic countries (Finland and Denmark), two in Switzerland and the rest in Northern Europe (UK, Netherlands and Germany).

As seen in Table 1, there were four articles on the general population $[9,12-14]$ and four on specific working population (nurses [8,15], hospital employees [10] and employees of factories [11]). One article [12] included only people with previous LBP. In all but one of the reports, participants were between 20 and 60 years, the eight article only provided the mean age with the SD (23.2(5.1) [15]. In no two articles was the duration of the entire study period or the numbers of surveys identical, ranging from 52 surveys over one year [12] to 4 surveys over 28 years [11]. Four of the studies used the Nordic Back Pain Questionnaire either in postal surveys $[9,10]$, through the internet or via postal diaries [12], or by computer assisted telephonic interview [14]. For the remaining four $[8,11,13,15]$, questionnaires of unknown source were used. Although the exact wording of the LBP question was not always the same, definitions of LBP were generally relatively similar (usually LBP in the past year) with only two concentrating on LBP in the past month $[8,12]$. One reported also on longstanding LBP [14] and another used the description 'severity', which we renamed 'duration', as it related to number of days in the past year and not severity of symptoms [12]. One of the articles related the recall period to the duration since the last survey [15].

Furthermore, LBP was not always described in the same way between studies. In four articles $[8,11,13,15]$, the presence or absence of LBP in the past year was measured at each survey without further specification; in two articles $[9,10]$, LBP was classified in relation to duration during the past year; one article [12] categorized LBP according to severity and persistence of symptoms, whereas another article [14] used two different definitions for longstanding LBP in the past year ( $>3$ months in two surveys and $>1$ month in one survey).

\section{Quality of studies}

Table 2 shows that all articles had a fairly high score according to the quality checklist; none scored less than $7 / 11$. For this reason we took no further notice of the quality score, as we considered all articles to be credible. Nevertheless, it is worth noticing that two of the articles did not clearly deal with the issue of representativeness $[8,10]$. Other quality issues of interest are described below.

Not all reported the response rate in percentages $[8,10-12,15]$ but when reported these ranged from $34 \%$ [13] to $96 \%$ [9]. In the article in which data were collected 52 times (every week) during one year [12], participants who completed at least $50 \%$ of these questionnaires were defined as 'responders', resulting in a total response rate of $90 \%$. However, as is often the case in prospective studies, not everybody reported response rates for each subsequent survey clearly in relation to either those invited to participate in the first survey or (if that number was unknown) at least in relation to the number of participants at baseline. A calculation based on these figures reduced the response rates to a range from $21 \%$ [10] to $65 \%$ [14]. Furthermore, only five reports $[9-11,14,15]$ discussed the potential impact that the non-responders may have on the results and in only one article were data modeled for this group [9].

\section{Course of LBP}

Table 3 gives the results on the course of absence or presence of LBP for each article. Interpretation of the natural course of LBP is reported below both for those without and those with LBP at baseline, in relation to stability, fluctuation, worsening or improvement.

\section{No LBP at baseline}

As shown in Table 3, in six of the seven relevant studies, relatively substantial stable stable subgroups were identified of people who continued to be LBP free. In one study [8], absence of LBP at baseline was said to be predictive of continued absence of LBP. In another study [13], absence of LBP was noted to be the most common subgroup of 32 possible combinations and in another [9], almost $50 \%$ belonged to this category. According to one of these six studies, approximately $10 \%$ with no LBP at baseline reported long standing LBP five and ten years later [14]. Further, at the 28 years follow-up, LBP was reported by $2 / 3$ of those initially free of LBP [11].

\section{LBP at baseline}

The course over time in those who reported LBP at baseline seemed to be somewhat more heterogeneous (Table 3). In all of the seven relevant studies, definite stable subgroups of continued LBP were noted and improvement (becoming pain free) was never reported to be a common finding. According to one article [11], LBP was a stable occurrence five, ten and 28 years down the track, and also when surveyed weekly over one year [12], persistence of symptoms was noted in the majority of participants.

When fluctuation occurred $(n=4)$, it seemed most common between neighboring groups $[9,10,14,15]$. One study identified also a relatively small subgroup of people that worsened over time [10].

\section{Additional analyses}

There were no obvious differences in our results in relation to type of study population or number and spacing of surveys, with the possible exception of the results for 
Table 1 Descriptive checklist

\begin{tabular}{|c|c|c|c|c|c|c|c|}
\hline $\begin{array}{l}\text { Reference } \\
\text { number }\end{array}$ & $\begin{array}{l}I^{\text {st }} \text { author } \\
\text { Year } \\
\text { Country }\end{array}$ & $\begin{array}{l}\text { Type of } \\
\text { population } \\
\text { (Age range) }\end{array}$ & $\begin{array}{l}\text { Specific inclusion } \\
\text { criteria in } \\
\text { relation to LBP }\end{array}$ & $\begin{array}{l}\text { Method } \\
\text { of data } \\
\text { collection }\end{array}$ & $\begin{array}{c}\text { Definition of relevant } \\
\text { LBP outcome variable } \\
\text { (Anatomical site, recall periods, } \\
\text { duration, severity, consequence) }\end{array}$ & $\begin{array}{l}\text { Years or time } \\
\text { of surveys }\end{array}$ & $\begin{array}{l}\text { Numbers of } \\
\text { surveys over the } \\
\text { study period/years }\end{array}$ \\
\hline \multirow[t]{2}{*}{ [8] } & \multirow{2}{*}{$\begin{array}{l}\text { Smedley } \\
1998 \\
\text { UK }\end{array}$} & \multirow{2}{*}{$\begin{array}{c}\text { University } \\
\text { hospital-based } \\
\text { nurses, all types } \\
\text { (19-64 years) }\end{array}$} & \multirow[t]{2}{*}{ NA } & \multirow[t]{2}{*}{$Q^{\text {aire }}$} & \multirow{2}{*}{$\begin{array}{l}\text { LBP }>1 \text { day in } \\
\text { the past month }\end{array}$} & 1993 & \multirow[t]{2}{*}{$8 / 2$} \\
\hline & & & & & & $\begin{array}{l}\text { Every } 3 \text { month } \\
\text { Until } 1995\end{array}$ & \\
\hline \multirow[t]{3}{*}{ [9] } & \multirow{3}{*}{$\begin{array}{l}\text { Hestbaek } \\
2003 \\
\text { Denmark }\end{array}$} & \multirow{3}{*}{$\begin{array}{l}\text { Men and women } \\
\text { living in a Danish } \\
\text { municipality } \\
\text { (30-50 years) }\end{array}$} & \multirow[t]{3}{*}{ NA } & \multirow[t]{3}{*}{$Q^{\text {aire }}$} & \multirow{3}{*}{$\begin{array}{l}\text { Number of days with } \\
\text { LBP in the past year } \\
(0 ; 1-7 ; 8-30 ;>30) \text { days }\end{array}$} & 1991 & \multirow[t]{3}{*}{$3 / 5$} \\
\hline & & & & & & 1992 & \\
\hline & & & & & & 1995 & \\
\hline \multirow[t]{3}{*}{ [10] } & \multirow{3}{*}{$\begin{array}{l}\text { Maül } \\
2003 \\
\text { Germany }\end{array}$} & \multirow{3}{*}{$\begin{array}{l}\text { University } \\
\text { hospital-based } \\
\text { nurses (?) }\end{array}$} & \multirow[t]{3}{*}{ NA } & \multirow[t]{3}{*}{$Q^{\text {aire }}$} & \multirow{3}{*}{$\begin{array}{l}\text { Number of days with } \\
\text { LBP past year } \\
(0 ; 1-7 ; \geq 8)^{*} \text { days }\end{array}$} & 1991 & \multirow[t]{3}{*}{$3 / 9$} \\
\hline & & & & & & 1992 & \\
\hline & & & & & & 1999 & \\
\hline \multirow[t]{4}{*}{ [11] } & \multirow{4}{*}{$\begin{array}{l}\text { Kääriä } \\
2006 \\
\text { Finland }\end{array}$} & \multirow{4}{*}{$\begin{array}{l}\text { The employees } \\
\text { in factories, } \\
\text { all types } \\
\text { (at least } 47 \text { yrs) }\end{array}$} & \multirow[t]{4}{*}{ NA } & \multirow[t]{4}{*}{$Q^{\text {aire }}$} & \multirow{4}{*}{$\begin{array}{l}\text { LBP in the } \\
\text { past year }\end{array}$} & 1973 & \multirow[t]{4}{*}{$4 / 28$} \\
\hline & & & & & & 1978 & \\
\hline & & & & & & 1983 & \\
\hline & & & & & & 2000 & \\
\hline \multirow[t]{2}{*}{ [12] } & \multirow[t]{2}{*}{$\begin{array}{l}\text { Tamcan } \\
2010 \\
\text { Switzerland }\end{array}$} & \multirow[t]{2}{*}{$\begin{array}{l}\text { General } \\
\text { population } \\
\text { (?) }\end{array}$} & \multirow{2}{*}{$\begin{array}{l}\text { Those who report } \\
\text { LBP in 2002-03 } \\
\text { and who still } \\
\text { report LBP in } 2005\end{array}$} & \multirow[t]{2}{*}{$\begin{array}{l}\text { Internet-based } \\
\text { diaries or } \\
\text { postal diaries }\end{array}$} & $\begin{array}{l}\text { LBP past month } \\
\text { at week } 1 \text { and } \\
\text { week } 53\end{array}$ & 2005 & \multirow[t]{2}{*}{$53 / 1$} \\
\hline & & & & & $\begin{array}{l}\text { Intensity of pain } \\
\text { each week } \\
\text { between }\end{array}$ & Every week & \\
\hline \multirow[t]{5}{*}{ [13] } & & General & NA & Computer assisted & In past year >1 month & 1999 & $5 / 5$ \\
\hline & $\begin{array}{c}2011 \\
\text { Switzerland }\end{array}$ & $\begin{array}{l}\text { population } \\
\text { (?) }\end{array}$ & & $\begin{array}{l}\text { telephonic } \\
\text { interviews }\end{array}$ & of bad BP or LBP & 2000 & \\
\hline & & & & & & 2001 & \\
\hline & & & & & & 2002 & \\
\hline & & & & & & 2003 & \\
\hline
\end{tabular}


Table 1 Descriptive checklist (Continued)

\begin{tabular}{|c|c|c|c|c|c|c|c|}
\hline \multirow[t]{3}{*}{ [14] } & \multirow{3}{*}{$\begin{array}{l}\text { Van Oostrom } \\
2011 \\
\text { The Netherlands }\end{array}$} & \multirow{3}{*}{$\begin{array}{l}\text { General } \\
\text { population } \\
\text { (20-60) }\end{array}$} & \multirow[t]{3}{*}{ NA } & \multirow[t]{3}{*}{$Q^{\text {aire }}$} & $\begin{array}{l}\text { Persistent } \\
\text { LBP past year }\end{array}$ & 1993-97 & \multirow[t]{3}{*}{$3 / 10$} \\
\hline & & & & & \multirow{2}{*}{$\begin{array}{l}\text { Defined as more } \\
\text { than three months } \\
\text { (study } 1 \text { and } 3 \text { ) } \\
\text { and more than } \\
\text { one month } \\
\text { (study 2) }\end{array}$} & 1998-02 & \\
\hline & & & & & & 2003-07 & \\
\hline \multirow[t]{4}{*}{ [15] } & \multirow[t]{4}{*}{$\begin{array}{l}\text { Videman } \\
2005 \\
\text { Finlande }\end{array}$} & \multirow[t]{4}{*}{$\begin{array}{l}\text { Nursing } \\
\text { students }\end{array}$} & \multirow[t]{4}{*}{ NA } & \multirow[t]{4}{*}{$Q^{\text {aire }}$} & $\begin{array}{l}\text { BP past } 4 \text { month, } \\
\text { past year and } \\
\text { past } 4 \text { years }\end{array}$ & Baseline & \multirow[t]{4}{*}{$9 / 7.5$} \\
\hline & & & & & \multirow{3}{*}{$\begin{array}{c}(0 ; 1-7 ; 8-30 ;>30) \text { days } \\
\text { but not daily, } \\
\text { and daily }\end{array}$} & $\begin{array}{l}\text { Every } 4 \text { month } \\
\text { during } 2 \text { years }\end{array}$ & \\
\hline & & & & & & 1 year after school & \\
\hline & & & & & & 5 year after school & \\
\hline
\end{tabular}

*Mentionned in methods. Reclassified from 'severity' to duration.

$N A$ : Not applicable. 
Table 2 Quality checklist

\begin{tabular}{|c|c|c|c|c|c|c|c|c|c|c|c|c|}
\hline \multirow{3}{*}{$\begin{array}{l}\text { Ref } \\
\mathbf{N}^{\circ}\end{array}$} & \multicolumn{5}{|c|}{ Representativeness } & \multicolumn{3}{|c|}{ Quality of data } & \multicolumn{4}{|c|}{ Definition of LBP } \\
\hline & $\begin{array}{l}\text { Response } \\
\text { rates in } \\
\text { relation to } \\
\text { invited study } \\
\text { sample at } \\
\text { baseline. }\end{array}$ & $\begin{array}{l}\text { Sample } \\
\text { sizes }\end{array}$ & $\begin{array}{c}\mathrm{N} / \% \\
\text { response at } \\
\text { all surveys } \\
\text { based on } \\
\text { number of } \\
\text { participants } \\
\text { at first } \\
\text { survey }\end{array}$ & $\begin{array}{l}\text { At least one of } \\
\text { the following: } \\
\text { Whole target } \\
\text { population; } \\
\text { Randomly } \\
\text { selected sample; } \\
\text { or Sample } \\
\text { stated to } \\
\text { represent } \\
\text { general } \\
\text { population } \\
\end{array}$ & $\begin{array}{l}\text { At least one of the } \\
\text { following: Reasons for } \\
\text { non response } \\
\text { described; Non- } \\
\text { responders described; } \\
\text { Comparison } \\
\text { responders-non- } \\
\text { responders; or } \\
\text { Comparison of sample } \\
\text { and target population }\end{array}$ & $\begin{array}{c}\text { Same } \\
\text { mode of } \\
\text { data } \\
\text { collection } \\
\text { for all } \\
\text { subjects, } \\
\text { and all } \\
\text { surveys }\end{array}$ & $\begin{array}{c}\text { Same } \\
\text { definition(s) } \\
\text { of LBP } \\
\text { outcome } \\
\text { variable } \\
\text { used for } \\
\text { all subjects } \\
\text { at all } \\
\text { survey }\end{array}$ & $\begin{array}{l}\text { At least one of } \\
\text { the following: } \\
\text { Questionnaires, } \\
\text { diaries, or } \\
\text { interviews } \\
\text { validated; } \\
\text { Tested for } \\
\text { reproductibility } \\
\text { or Tested in } \\
\text { pilot study }\end{array}$ & $\begin{array}{c}\text { Precise } \\
\text { anatomical } \\
\text { delineation of } \\
\text { lumbar area; } \\
\text { or Reference } \\
\text { to easily } \\
\text { obtainable } \\
\text { article that } \\
\text { contains such } \\
\text { specification }\end{array}$ & $\begin{array}{c}\text { Further } \\
\text { specification of } \\
\text { definition of LBP; } \\
\text { Questions put to } \\
\text { study subjects } \\
\text { quoted; or } \\
\text { Reference to easily } \\
\text { obtainable article } \\
\text { that contains such } \\
\text { specification }\end{array}$ & $\begin{array}{c}\text { Recall } \\
\text { periods } \\
\text { specified }\end{array}$ & $\begin{array}{c}\text { Quality } \\
\text { score: } \\
\text { Number } \\
\text { of 'Yes'/ } \\
\text { Number } \\
\text { of } \\
\text { relevant } \\
\text { items }\end{array}$ \\
\hline & $\begin{array}{l}\text { If new study } \\
\text { subjects } \\
\text { invited, } \\
\text { response } \\
\text { rates } \\
\text { calculated } \\
\text { based on } \\
\text { number of } \\
\text { invited } \\
\text { participants } \\
\text { at each } \\
\text { survey }\end{array}$ & & & $\underline{\text { (Yes/No) }}$ & (Yes/No) & (Yes/No) & (Yes/No) & $\underline{\text { (Yes/No) }}$ & $\underline{\text { (Yes/No) }}$ & $\underline{\text { (Yes/No) }}$ & (Yes/No) & \\
\hline \multirow[t]{8}{*}{ [8] } & $\begin{array}{c}1088 / 2405= \\
45 \%\end{array}$ & 1088 & $470 / 1165$ & No & Yes & Yes & Yes & No & Yes & Yes & Yes & $9 / 11$ \\
\hline & $\begin{array}{c}999 / 2405= \\
41 \%\end{array}$ & 999 & $40 \%$ & & & & & & & & & $82 \%$ \\
\hline & $\begin{array}{c}878 / 2405= \\
36 \%\end{array}$ & 878 & & & & & & & & & & \\
\hline & $\begin{array}{c}827 / 2405= \\
34 \%\end{array}$ & 827 & & & & & & & & & & \\
\hline & $\begin{array}{c}758 / 2405= \\
31 \%\end{array}$ & 758 & & & & & & & & & & \\
\hline & $\begin{array}{c}700 / 2405= \\
29 \%\end{array}$ & 700 & & & & & & & & & & \\
\hline & $\begin{array}{c}614 / 2405= \\
25 \%\end{array}$ & 614 & & & & & & & & & & \\
\hline & $\begin{array}{c}599 / 2405= \\
25 \%\end{array}$ & 599 & & & & & & & & & & \\
\hline
\end{tabular}


Table 2 Quality checklist (Continued)

[9] $1309 / 2000=1309 \quad 765 / 1309$ Yes

Yes

Yes

Yes

Yes

Yes

Yes

$11 / 11$

$198 / 2000=\quad 1198 \quad 58 \%$

$60 \%$

$813 / 2000=\quad 813$ $41 \%$

[10] $1307 / 1963=\quad 1307 \quad 269 / 1307$

$$
67 \%
$$$$
21 \%
$$

$1159 / 2185$

$$
1159
$$$$
\underset{58 \%}{1584 / 2744=} \quad 1584
$$

[11] $\begin{gathered}902 / 1057= \\ 85 \%\end{gathered}$

$748 / 1057=$ $71 \%$

participated

Used in analysis: 305/340 =

(95-100\% responses)

7791
6335
575
4885
4354

[14] $6118 / 7769=-4354$ $4917 / 7769=\quad 4917$ $65 \%$

$$
63 \%
$$




Yes

Yes

No

Yes

Yes

Yes

$\begin{array}{ll}\text { Yes } & 7 / 11 \\ & 64 \%\end{array}$

?/308

$? / 308$

$? / 308$

?/308

?/308

?/308

$197 / 308$

$174 / 308$ 
Table 3 Results

\begin{tabular}{|c|c|c|c|c|c|c|}
\hline \multirow{2}{*}{$\begin{array}{l}\text { At } \\
\text { Baseline }\end{array}$} & \multirow{2}{*}{$\begin{array}{l}\text { Reference } \\
\mathrm{N}^{\circ}\end{array}$} & \multicolumn{4}{|c|}{ Development of LBP over time } & \multirow[t]{2}{*}{ Comments } \\
\hline & & Stable & Fluctuating & Worsening & Improving & \\
\hline \multirow[t]{9}{*}{ No LBP } & [8] & $\begin{array}{l}\text { No LBP at BL was highly predictive of } \\
\text { future absence of pain throughout } 8 \\
\text { surveys over } 2 \text { years }\end{array}$ & & & NA & \\
\hline & [9] & $\begin{array}{l}45 \% \text { with no pain at } 3 \text { surveys over } \\
5 \text { years }\end{array}$ & & & NA & \\
\hline & [10] & $\begin{array}{l}70 \% \text { no pain at second survey and } \\
57 \% \text { at } 3^{\text {rd }} \text { survey over } 8 \text { years }\end{array}$ & & & NA & \\
\hline & [11] & $\begin{array}{l}67 \% \text { and } 63 \% \text { respectively no pain at } \\
2^{\text {nd }} \text { and } 3^{\text {rd }} \text { survey over } 28 \text { years }\end{array}$ & & $\begin{array}{l}64 \% \text { had LBP at the } 4^{\text {th }} \\
\text { survey ( } 28 \text { years later) }\end{array}$ & NA & \\
\hline & [12] & NA & NA & NA & NA & $\begin{array}{l}\text { Not applicable: all } \\
\text { participants were chosen } \\
\text { because they had LBP }\end{array}$ \\
\hline & [13] & $\begin{array}{l}\text { The most frequent course was no BP } \\
\text { each year over } 5 \text { years }(35 \%)\end{array}$ & & & NA & \\
\hline & \multirow[t]{2}{*}[14]{} & $\begin{array}{l}-29 \% \text { of the population was free of } \\
\text { LBP at } 3 \text { surveys over } 10 \text { years }\end{array}$ & & \multirow{2}{*}{$\begin{array}{l}-11 \% \text { developed long } \\
\text { standing LBP at } 2^{\text {nd }} \text { and } 3^{\text {rd }} \\
\text { survey over } 10 \text { years }\end{array}$} & \multirow[t]{2}{*}{ NA } & \\
\hline & & $\begin{array}{l}-62 \% \text { never had long standing LBP at } \\
3 \text { surveys over } 10 \text { years }\end{array}$ & & & & \\
\hline & [15] & Stable (visual analysis) & & & & \\
\hline \multirow[t]{6}{*}{$\begin{array}{l}\text { Presence } \\
\text { of LBP }\end{array}$} & [8] & $\begin{array}{l}\text { Presence of } L B P \text { at } B L \text { was highly } \\
\text { predictive of future pain throughout } \\
8 \text { surveys over } 2 \text { years }\end{array}$ & & & & \\
\hline & [9] & $\begin{array}{l}\text { If }>30 \text { days of } L B P \text { at } B L: 39 \% \text { in the } \\
\text { same category after } 1 \text { and } 5 \text { years }\end{array}$ & $\begin{array}{l}\text { If } 1-30 \text { days of LBP at BL: } 62 \% \text { fluctuated to } \\
\text { the neighboring groups over } 5 \text { years }\end{array}$ & & & \\
\hline & [10] & $\begin{array}{l}38 \% \text { have the same intensity of LBP } \\
\text { at } 3 \text { surveys over } 8 \text { years }\end{array}$ & $\begin{array}{l}27 \% \text { of LBP (intensity) fluctuated; } \\
\text { movements between extremes groups were } \\
\text { rare }(12 \%) \text { at } 3 \text { surveys over } 8 \text { years }\end{array}$ & $\begin{array}{l}17 \% \text { of LBP (intensity) } \\
\text { increased at } 3 \text { surveys over } \\
8 \text { years }\end{array}$ & $\begin{array}{l}19 \% \text { of LBP (intensity) } \\
\text { decreased at } 3 \text { surveys over } \\
8 \text { years }\end{array}$ & \\
\hline & \multirow[t]{2}{*}{ [11] } & $\begin{array}{l}75,73 \text { and } 88 \% \text { were symptomatic at } \\
3 \text { FUs over } 28 \text { years }\end{array}$ & & & & \\
\hline & & $\begin{array}{l}31 \% \text { of the subjects reported LBP in } \\
\text { all } 4 \text { surveys }\end{array}$ & & & & \\
\hline & [12] & $\begin{array}{l}\text { Stability of severity and frequency of } \\
\text { LBP was high in } 4 \text { periods over } \\
1 \text { year }\end{array}$ & & & $\begin{array}{l}\text { 3\% reported no pain after BL } \\
\text { throughout the weekly } \\
\text { surveys over one year }\end{array}$ & \\
\hline
\end{tabular}


Table 3 Results (Continued)

\begin{tabular}{|c|c|c|c|}
\hline [13] & $\begin{array}{l}\text { The most frequent course was BP } \\
\text { each year over } 5 \text { years (14\%) }\end{array}$ & & \\
\hline [14] & $\begin{array}{l}6 \% \text { had long standing LBP at } \\
3 \text { surveys over } 10 \text { years }\end{array}$ & $\begin{array}{l}11 \% \text { had long standing LBP only at some } \\
\text { surveys over } 10 \text { years }\end{array}$ & $\begin{array}{l}10 \% \text { had recovered from } \\
\text { long lasting low back } \\
\text { pain at } 2^{\text {nd }} \text { and } 3^{\text {rd }} \text { survey }\end{array}$ \\
\hline [15] & $\begin{array}{l}\text { For those who had more than } 8 \text { days } \\
\text { of BP during that first year } \\
\text { (visual analysis) }\end{array}$ & $\begin{array}{l}\text { For those who have between } 1-7 \text { days of } \\
\text { BP the first year of the } 5-y \text { r study period } \\
\text { (visual analysis) }\end{array}$ & \\
\hline
\end{tabular}


the 28-year follow-up that indicated that LBP will occur in the end among the previously 'protected' nonsufferers [11].

\section{Discussion}

The purpose of this review was to gain an understanding of the natural course of LBP. The conclusion is that the LBP status at baseline is predictive of the future course and, probably, in particular for those who do not have LBP at baseline.

The eight studies that were identified were all of relatively high quality, judging by their quality scores, but their study approaches were dissimilar in relation to definition of LBP, method of data collection, number of surveys, time between surveys, and type of population. That the results nevertheless pointed in the same direction, strengthens the validity of these findings. However, it would have been helpful if studies could have reported their data more clearly and systematically, as otherwise it is difficult to extract the relevant information from the text.

In particular, it would have been more informative if researchers could have reported more clearly the percentage of drop-outs at the various surveys and attempted to take into account the possible effect of missing data. Although several authors [9-11,14,15] considered potential differences between responders and non-responders, only one [9] visualized them in their result section and even took them into account in a best case and worst case analysis, which obviously can be important in studies with large dropout rate numbers, as is often the case in studies with multiple follow-ups over long periods of time.

This systematic and critical review was done independently by two readers with no particular interest in the outcome of the review. Nonetheless, it suffers the same potential weaknesses as many other similar reviews. For example, it is not sure that all relevant articles were retrieved, if checklists were relevant, or if the information was properly interpreted.

However, this topic is fairly new, indicating that there would not be numerous studies and those that have been published were easily noticed. Further, our thorough citation search did not result in any additional publications, although, admittedly, one retrieved article [15] failed to be captured in our search procedure. Still, it is possible that this type of data can be found interspersed between the main messages of articles with other specific objectives than describing the natural course of LBP. It is possible that we may have missed those. The grids for systematic data collection were designed to meet our needs and the quality checklist was a previously published and used checklist for this type of studies with only minor adjustments to fulfill the needs of the present review. Another type of quality checklist could of course have resulted in a different view of which articles to accept for analysis. Although the literature sometimes was difficult to extract and interpret, partly because not all articles had the same primary research objectives as we had, it was never necessary to seek arbitration from the third author, indicating good consensus between reviewers although, of course, not guaranteeing accuracy.

Another potential shortcoming could be that we included studies also from the working population. Such studies could have biased study samples either through a healthy worker effect [16] or the opposite, in the case of physically undemanding jobs. In our case, a healthy worker effect would probably not be pronounced, as we on purpose did not include working populations representing heavy manual labor. Also, there were no obvious differences in outcomes between studies of the general and working populations.

\section{Conclusion}

The results of this survey indicate that, in the general population, absence of LBP at one time in life is a blessing, in that it will indicate also a pain-free future at last for a fairly large number of years. On the other hand, those with LBP will fairly consistently report LBP again.

\section{Additional file}

Additional file 1: Appendices. 1: Descriptive checklist for a systematic literature review on the natural course of low back pain (LBP). 2: Quality checklist for a systematic literature review on the natural course of LBP. $\mathbf{3}$ : List of 10 articles that were excluded from the literature review in concordance with our inclusion and exclusion criteria.

\section{Competing interests}

One of the authors (CLY) was co-author on one of the reviewed articles. However, the review was performed by two of the authors, and there were no discrepancies between these two on the findings from that article. Otherwise, the authors state that they have no competing interest.

\section{Authors' contributions}

All authors helped to plan the review. NL and CLY performed the literature review. NL and CLY interpreted the findings. NL wrote the first draft. All authors participated in completing the manuscript. All authors read and approved the final manuscript.

\section{Author details}

'Complexité, Innovation et Activités Motrices et Sportives, Bâtiment 335, UFR STAPS, Université Paris Sud-11, Orsay Cedex 91405, France. ${ }^{2}$ Institut FrancoEuropéen de Chiropratique, 72 Chemin de la Flambère, Toulouse 31300, France. ${ }^{3}$ Research Department, Spine Center of Southern Denmark, Hospital Lillebaelt and Institute of Regional Health Services Research, University of Southern Denmark, Ostre Hougvej 55, Middelfart, Denmark. 


\section{References}

1. Spitzer WO, LeBlanc RE, Dupuis MS: Scientific approach to the assessment and management of activity-related spinal disorders. In monograph for clinicians: report of the Quebec task force on spinal disorders. Spine 1987, 12:s16-s21.

2. Waddell G: A new clinical model for the treatment of low back pain Spine 1987, 12(7):632-641.

3. Stanton TR $\sqcup$, Maher $C G$, Hancock MJ: How do we define the condition 'recurrent low back pain'? A systematic review. Eur Spine J 2010, 19:533-539.

4. Von Korff MDK: Chronic pain reconsidered. Pain 2008, 138(2):267-276

5. Leboeuf-Yde C, Jensen RK, Axen I: Absence of low back pain in patients followed weekly over one year with automated text messages. Chiropr \& Man Th 2012, 20:9.

6. Dunn K, Jordan K, Croft P: Characterizing the course of low back pain: a latent class analysis. Am J Epidemiol 2006, 163(8):754-761.

7. Leboeuf-Yde C, Lauritzen JM: The prevalence of low back pain in the literature. Spine 1995, 20(19):2112-2118.

8. Smedley J, Inskip H, Cooper C, Coggon D: Natural history of low back pain: a longitudinal study in nurses. Spine 1998, 23(22):2422-2426.

9. Hestbaek L, Engberg M, Lauritzen T, Bruun NH, Manniche C: The course of low back pain in a general population. Results from a 5 -year prospective study. J Manipulative Physiol Ther 2003, 26(4):213-219.

10. Maul I, Läubli T, Klipstein A, Krueger H: Course of low back pain among nurses: a longitudinal study across eight years. Occup Environ Med 2003, 60:497-503.

11. Kääriä S, Luukkonen R, Riihimäki H, Kirjonen J, Leino-Arjas P: Persistence of low back pain reporting among a cohort of employees in a metal corporation: A study with 5-, 10-, and 28-year follow-ups. Pain 2006, 120:131-137.

12. Tamcan O, Mannion AF, Eisenring C, Horisberger B, Elfering A, Müller U: The course of chronic and recurrent low back pain in the general population. Pain 2010, 150(3):451-457.

13. Kolb E, Canjuga M, Bauer GF, Läubli T: Course of back pain across 5 years. Spine 2011, 36(4):E268-E273.

14. van Oostrom SH, Verschuren VMM, de vet HCW, Picavet HS: Ten year course of low back pain in an adult population-based cohort - The Doetinchem Cohort Study. Eur Journal of Pain 2011, 15:993-998.

15. Videman T, Ojajärvi A, Riihimäki H, Troup JDH: Low back pain among nurses. Spine 2005, 30(20):2334-2341.

16. McMichael A: Standardized mortality ratios and the "healthy worker effect": Scratching beneath the surface. J Occup Med 1976, 18(3):165-168.

doi:10.1186/2045-709X-20-33

Cite this article as: Lemeunier et al:: The natural course of low back pain: a systematic critical literature review. Chiropractic \& Manual Therapies 2012 20:33.

\section{Submit your next manuscript to BioMed Central and take full advantage of:}

- Convenient online submission

- Thorough peer review

- No space constraints or color figure charges

- Immediate publication on acceptance

- Inclusion in PubMed, CAS, Scopus and Google Scholar

- Research which is freely available for redistribution 